\title{
ESTIMATES OF PRE- AND PERINATAL MORTALITY IN THE NEW ZEALAND ROMNEY MARSH EWE
}

\author{
I. PRE- AND PERINATAL MORTALITY IN THOSE \\ EWES THAT CONCEIVED TO ONE SERVICE
}

\author{
T. D. QUINLIVAN,* C. A. MARTIN,* W. B. TAYLOR $\dagger$ \\ AND I. M. CAIRNEY $\dagger$ \\ *New Zealand Romney Marsh Survey, Feilding, and \\ †New Zealand Sheep and Beef Cattle Survey, Wellington, Nerw Zealand
}

(Received 22nd September 1965)

\begin{abstract}
Summary. The results of two slaughter observations conducted in 1963 and 1964 that involved the natural mating of $9932 \frac{1}{2}$-year-old New Zealand Romney Marsh ewes, half of which were parous, the remainder non-parous in the previous year, are described. The aim of the observation was to measure the loss through non-fertilization, embryonic, foetal and lamb death throughout pregnancy by slaughtering equal numbers at $2,18,40$ and 140 days post coitum, and allowing a control group to lamb.

This paper presents the data obtained from those ewes that were mated and conceived to one service. In 1964, from a comparable ovulation rate of $139 \%$ and $143 \%$ and a fertilization rate of $91.1 \%$ and $83.3 \%$ for the parous and non-parous ewes respectively, the period of greatest prenatal mortality in those ewes that did not return to service was in the first 30 days of pregnancy, $22 \%$ and $16.6 \%$ of the fertilized ova being unaccounted for as live embryos during this stage. The period of maximum loss occurred in the period immediately preceding the 18th day; this accounted for $50 \%$ of the overall mortality in the two groups of ewes in the first 30 days of pregnancy. A similar pattern was obtained during a preliminary investigation in 1963.

Of the embryos alive at 30 days, $1.3 \%$ and $5.3 \%$ from the parous and non-parous ewes, respectively, underwent either abortion or mummification. The overall estimate of prenatal death, excluding non-fertilization, was $23.3 \%$ and $20.9 \%$ for the two groups of ewes respectively.

Perinatal loss amounted to $8.3 \%$ and $26.7 \%$ for the two respective classes of ewes, this presenting a total estimated overall pre- and perinatal loss of $29.6 \%$ and $41.7 \%$ for the parous and non-parous ewes respectively, calculated as the percentage of fertilized ova that failed to produce a viable lamb.
\end{abstract}

\section{INTRODUCTION}

There is a paucity of published information on estimates of prenatal mortality in the New Zealand Romney Marsh ewe, although considerable published and 
unpublished data are available on perinatal loss both in pedigree and commercial flocks.

The subject of prenatal mortality has been reviewed with reference to farm animals, and more particularly the bovine, by Laing (1952), Casida (1953), Robinson (1957) and Hanly (1961). In each case the lack of information on the time of embryonic death was emphasized.

Various estimates of prenatal loss in the ewe (excluding non-fertilization) range from 7.3\% (Hammond, 1921), 8\% (Winters \& Feuffel, 1936), 16\% (Brambell, 1948; Henning, 1939), 20.5\% (Dutt, 1954) and 30\% (Hulet, Voigtlander, Pope \& Casida, 1956).

Because of the lack of published information on embryonic loss under New Zealand conditions two slaughter investigations were designed to examine the four factors that affect lambing performance, namely, the ovulation rate, fertilization rate and the degree of pre- and perinatal mortality.

\section{MATERIALS AND METHODS}

\section{3 observation}

\section{FLOCK STUDIES}

This preliminary investigation involved $2082 \frac{1}{2}$-year-old Romney ewes, 106 of which were parous and 102 non-parous when mated for the first time the previous year. These were obtained from fifty-two pedigree Romney flocks in the southern half of the North Island of New Zealand and were naturally mated with four Romney Marsh rams whose semen quality, examined on six occasions, was considered commensurate with high fertility. Before 12th March 1963, when the rams and ewes were joined, the ewes were allocated randomly to three groups to be slaughtered at 2, 18 and 30 days, respectively. All rams were fitted with Sire-sine harnesses and crayons (Radford, Watson \& Wood, 1960) and were semen-tested throughout the mating period of 51 days. As each ewe was mated by the ram a colour sequence to denote due date of slaughter was used. Examination of the flock for fresh matings and ewes due for slaughter took place every $24 \mathrm{hr}$. All ewes that returned to service were allocated into a 2-day slaughter group.

\section{4 observation}

Seven hundred and eighty-five $2 \frac{1}{2}$-year-old Romney ewes, 394 of which were parous and 391 non-parous as 2-year-olds the previous year, were used in this observation. All were derived from 120 pedigree Romney flocks in the southern half of the North Island. As in the 1963 observation the reproductive status of each ewe was supplied by each flockmaster before delivery in early February. This information was checked against stud records to ensure accuracy. Before mating all ewes were weighed and allocated randomly to five equal groups, four for slaughter at 2, 18, 30 and 140 days and a control group allowed to lamb. Twenty-four Romney Marsh rams ranging in age from $1 \frac{1}{2}$ to 5 years were available and, following semen examinations, those that were considered to be of maximum fertility were fitted with harnesses and crayons and liberated with the ewes on 20th March 1964. The number of rams with the ewes at any 
one time was determined by the rate at which the ewes came into oestrus, this at no time exceeding $2 \%$ of rams to ewes. A check on semen quality was kept on all sires throughout mating. The rams were withdrawn from the ewes on 10 th May, 51 days after introduction. A similar colour system to that employed in 1963 was used to identify a ewe's date of slaughter, and examination of the flock took place every $24 \mathrm{hr}$ for fresh matings. Throughout these papers reference is made to the number of services to which a ewe conceived. One or first service means the ewe has been mated at one oestrous period. Two or second service means the ewe has been mated at two successive oestrous periods. Three or third service means the ewe has been mated at three successive oestrous periods.

All ewes from the original 18-, 30- and 140-day groups that returned to first service were alternately allocated to either a 2-day or a 30-day slaughter group. All ewes in the original full-term group that returned to service either once or twice were retained in that flock and allowed to lamb. Those ewes that returned to service twice, apart from those in the full-term group, were all slaughtered 2 days after their third mating. Thus data are available on ewes that conceived to first, second and third service. This paper presents the data from those ewes that conceived to one service. The remaining data will be presented in a subsequent paper.

All ewes in the lambing group were vaccinated with a combined vaccine for Clostridium welchii Type D, Clos. chauvoei and Clos. septicum 2 to 4 weeks before the projected lambing date. Supervision during lambing for identification of lambs and general shepherding took place three times daily.

\section{POST-MORTEM STUDIES}

The principles of examination for the two observations were identical except that the 1964 experiment provided two additional groups (140-day and fullterm). From an examination of the genitalia, which took place approximately $20 \mathrm{~min}$ after slaughter, the following information was derived for the parous and non-parous ewes.

2-Day slaughter group

i. Ova shed (estimated from corpora lutea counted).

ii. Ova fertilized.

iii. Ova not fertilized.

iv. Abnormal ova.

v. Patency of the genital tract.

18, 30 and 140-Day slaughter groups

i. Number of corpora lutea.

ii. Number and status of recovered embryonic or foetal material.

iii. Patency of the genital tract.

iv. Autopsy on all lambs obtained at 140 days.

Full-term group

i. Lambs born, alive or dead.

ii. Autopsy on all lambs born. 


\section{RESULTS}

The following results pertain to the 2-day slaughter group and to those ewes in the other groups that conceived to first service (i.e. did not return to service in 17 days after mating).

TABLE 1

OVULATION RATE PERCENTAGE BY SLAUGHTER GROUPS

\begin{tabular}{l|r|r|r|r|r|r|r|r|r}
\hline & \multicolumn{4}{|c|}{1963} & \multicolumn{6}{|c}{1964} \\
\cline { 2 - 9 } & $\begin{array}{r}2- \\
\text { day }\end{array}$ & $\begin{array}{r}18- \\
\text { day }\end{array}$ & $\begin{array}{r}30- \\
\text { day }\end{array}$ & Total & $\begin{array}{c}2- \\
\text { day }\end{array}$ & $\begin{array}{l}18- \\
\text { day }\end{array}$ & $\begin{array}{c}30- \\
\text { day }\end{array}$ & $\begin{array}{r}140- \\
\text { day }\end{array}$ & Total \\
\hline No. of ewes & 70 & 68 & 69 & 207 & 158 & 160 & 155 & 155 & 628 \\
Not mated by ram & 4 & 2 & 2 & 8 & 2 & 1 & 7 & 3 & 13 \\
No. examined & 66 & 56 & 48 & 170 & 156 & 127 & 110 & 113 & 506 \\
Corpora lutea & 84 & 85 & 67 & 236 & 220 & 196 & 179 & 186 & 781 \\
Ovulation rate (\%)* & 127 & 152 & 140 & 138 & 141 & 154 & 163 & 165 & 154 \\
\hline
\end{tabular}

* Calculated as the percentage derived from number of corpora lutea counted from the number of ewes examined.

OVULATION RATE

Table 1 presents the data for the total ewes involved, ewes examined and ovulation rate percentage for the various slaughter groups in the 1963 and 1964 observations. The results obtained for the parous and non-parous ewes are combined as no significant difference existed between mean ovulation rates which were, during the 1963 and 1964 observations, $142 \%$ and $134 \%$, and $153 \%$ and $156 \%$ respectively, with differences of a similar order occurring between the different slaughter groups.

TABLE 2

FERTILIZATION RATE OF RECOVERED OVA IN THE

2-DAY SLAUGHTER GROUP

\begin{tabular}{l|c|c|c|c}
\hline & \multicolumn{2}{|c|}{1963} & \multicolumn{2}{c}{1964} \\
\cline { 2 - 5 } & $\begin{array}{c}\text { Parous } \\
\text { ewes }\end{array}$ & $\begin{array}{c}\text { Non- } \\
\text { parous } \\
\text { ewes }\end{array}$ & $\begin{array}{c}\text { Parous } \\
\text { ewes }\end{array}$ & $\begin{array}{c}\text { Non- } \\
\text { parous } \\
\text { ewes }\end{array}$ \\
\hline No. ova shed* & 48 & 36 & 110 & 110 \\
No. ova recovered & 41 & 31 & 100 & 97 \\
No. ova fertilized & 39 & 28 & 82 & 75 \\
No. ova not fertilized & 1 & 2 & 8 & 15 \\
No. abnormal ova & 1 & 1 & 10 & 7 \\
\hline
\end{tabular}

* Estimated from corpora lutea counted.

In both observations ten ewes in the 2-day slaughter group exhibited either delayed ovulation, manifest by the absence of follicle rupture and recent corpora lutea, or cystic follicles. 
FERTILIZATION RATE

The fertilization rate of recovered ova is presented in Table 2. Reference is made to abnormal ova which were deleted from any calculation of fertilization rate because of their doubtful status. Fractured ova were by far the most common abnormality.

Comparison between the parous and non-parous ewes, within the 1963 and 1964 observations showed no significant differences in fertilization rate.

EMBRYONIC STATUS AT 18 DAYS

The information available on embryos and/or embryonic debris derived from ewes slaughtered 18 days post coitum is presented in Table 3.

TABLE 3

EMBRYONIC VIABILITY AT 18 DAYS

\begin{tabular}{l|r|r|r|r}
\hline & \multicolumn{2}{|c|}{1963} & \multicolumn{2}{c}{1964} \\
\cline { 2 - 5 } & $\begin{array}{c}\text { Parous } \\
\text { ewes }\end{array}$ & $\begin{array}{c}\text { Non- } \\
\text { parous } \\
\text { ewes }\end{array}$ & $\begin{array}{c}\text { Parous } \\
\text { ewes }\end{array}$ & $\begin{array}{c}\text { Non- } \\
\text { parous } \\
\text { ewes }\end{array}$ \\
\hline Total ewes examined & 32 & 24 & 66 & 61 \\
Total corpora lutea & 49 & 36 & 103 & 93 \\
Viable embryos & 24 & 13 & 55 & 62 \\
A $_{1}$ & 3 & 4 & 15 & 11 \\
A A $_{2}$ & 10 & 7 & 4 & 5 \\
A3 & 37 & 24 & 74 & 78 \\
Total & & & & \\
Non-viable embryos & 1 & 1 & 2 & 2 \\
A $_{3}$ & 8 & 7 & 19 & 8 \\
B & 3 & 4 & 8 & 3 \\
C & 12 & 12 & 29 & 13 \\
Total & & & & \\
\hline
\end{tabular}

The following gross assessment of viability was used in the 1963 and 1964 observations.

$A_{1}$, Heartbeat observed on recovery.

$A_{2}$, No heartbeat observed on recovery but stimulated to beat with warm normal saline.

$A_{3}$, No heartbeat observed either on recovery or on stimulation.

$B$, No embryo recovered, membranes only observed.

C, No evidence of either embryo or membranes but corpus luteum present.

All $\mathrm{A}_{3}$ embryos with either a twin counterpart or a viable embryo of like size as a comparison, were submitted for histology so that a final positive diagnosis of viability could be made.

The $A_{1}, A_{2}$ and those $A_{3}$ embryos that on morphology in 1963 (Green \& Winters, 1945) and histology in 1964 showed no degenerative changes, were classed as alive. The remainder were those degenerate $A_{3}$ embryos, membranes only B and C.

The data presented in Table 3 show that 24.5 and $33.3 \%$, and 28.2 and $16.1 \%$ of the corpora lutea counted at 18 days, in the parous and non-parous 
ewes, in the two respective observations, could not be accounted for as live embryos.

No published evidence exists on the time embryonic membranes persist in utero following the death of the embryo, but histological evidence obtained from the 1964 specimens suggests that the disappearance of the embryo precedes that of the membranes. It may, therefore, be assumed that the death of the embryo in the cases where the membranes only were recovered took place at a stage earlier than the death of the non-viable $\mathrm{A}_{3}$ embryos recorded above.

Case $\mathrm{C}$ can be regarded as a loss at a stage earlier than cases $\mathrm{B}$ or $\mathrm{A}_{\mathbf{3}}$ unless when found in combination with a cystic corpus luteum. Only one ewe exhibited this in the 1963 observation, a live $\mathrm{A}_{1}$ embryo being present in combination with the case $\mathrm{C}$. Of the twelve ewes in the 1964 observation showing C, seven were in combination with live embryos, one showed two corpora lutea with complete absence of embryos or embryonic debris and four were derived from single ovulations. Disregarding the presence of cystic corpora lutea that occurred in five of the twelve ewes, of the remaining seven ewes only one showed a single ovulation. Ovarian activity suggested that this ewe could have had an extended inter-oestrus period of 19 to 20 days. The other six ewes exhibited case $\mathbf{G}$ in combination with other embryonic material. This overall appraisal of the derivation of $\mathrm{C}$ resolves itself into two considerations; firstly, as non-ovulation or, secondly, as a non-fertilization or embryonic loss. In those cases where a live embryo was associated with one categorized as case $\mathbf{C}$ a disparity in the diameter of the twin corpora lutea was observed, the mean and the range of the measurements being $9.6 \mathrm{~mm}(9.5$ to $9.8 \mathrm{~mm})$ and $4.9 \mathrm{~mm}$ $(2 \cdot 4$ to $7 \cdot 2 \mathrm{~mm})$.

TABLE 4

EMBRYONIC VIABILITY AT 30 DAYS

\begin{tabular}{l|c|c|c|c}
\hline & \multicolumn{2}{|c|}{1963} & \multicolumn{2}{c}{1964} \\
\cline { 2 - 3 } \cline { 5 - 6 } & $\begin{array}{c}\text { Parous } \\
\text { ewes }\end{array}$ & $\begin{array}{c}\text { Non- } \\
\text { parous } \\
\text { ewes }\end{array}$ & $\begin{array}{c}\text { Parous } \\
\text { ewes }\end{array}$ & $\begin{array}{c}\text { Non- } \\
\text { parous } \\
\text { ewes }\end{array}$ \\
\hline Total ewes examined & 26 & 22 & 60 & 50 \\
Total corpora lutea & 36 & 31 & 97 & 82 \\
Viable embryos (A) & 30 & 29 & 79 & 66 \\
Non-viable embryos & 4 & 1 & 2 & 5 \\
B & 2 & 1 & 16 & 11 \\
C & 6 & 2 & 18 & 16 \\
Total & & & & \\
\hline
\end{tabular}

EMBRYONIC VIABILITY AT 30 DAYS

The classification of embryos and/or embryonic debris derived from the ewes slaughtered at 30 days was as follows:

A, Embryo alive on recovery.

B, Membranes only present.

C, Corpus luteum present. No embryonic material recovered. 
No confirmatory histology was considered necessary in this group as all embryos recovered were alive as assessed by morphology and the presence of heartbeat. Table 4 presents the data for this group.

Category $B$ provided a measure of the mortality that occurred in those embryos alive at 18 days, whereas category $\mathrm{C}$ may be comparable to category $\mathrm{B}$ at 18 days and could constitute an earlier loss.

\section{FOETAL VIABILITY AT 140 DAYS}

The following classification of specimens obtained from the 140-day slaughter group was employed as an index of viability:

$\mathrm{F}_{1}$, Alive on recovery.

$\mathrm{F}_{2}$, Not alive but showing full body development commensurate with 140 days.

$F_{3}$, Mummified.

C, Complete absence of foetal material although a corpus luteum was present.

Table 5 presents the data for this group.

TABLE 5

FOETAL VIABILITY AT 140 DAYS

\begin{tabular}{l|c|c}
\hline & $\begin{array}{c}\text { Parous } \\
\text { ewes }\end{array}$ & $\begin{array}{c}\text { Non- } \\
\text { parous } \\
\text { ewes }\end{array}$ \\
\hline $\begin{array}{l}\text { Total ewes examined } \\
\text { No. of ewes aborted before slaughter } \\
\text { due }\end{array}$ & 60 & 53 \\
$\begin{array}{l}\text { No. of ewes showing no lamb at } \\
\text { slaughter* }\end{array}$ & - & 3 \\
Total corpora lutea & 95 & 91 \\
Viable foetuses (F $)$ & 76 & 71 \\
Non-viable foetuses & - & 1 \\
$\mathrm{~F}_{2}$ & - & 2 \\
$\mathrm{~F}_{3}$ & 19 & 17 \\
Cotal & 19 & 20 \\
\hline
\end{tabular}

* These ewes at slaughter showed no evidence of foetal material although they had not returned to service. These ewes were included in the calculation of ovulation rate for the non-parous group.

$\dagger \mathbf{C}$ provides a measure of the instances where in the case of two corpora lutea only one live foetus was present.

It is seen that from $20 \%$ and $22 \%$ of the corpora lutea recorded for the parous and non-parous ewes respectively, no embryonic or foetal material was recovered. Of the recovered foetuses, $2.7 \%$ were mummified and only $1.4 \%$ showed body development consistent with the 140-day period with evidence of death and autolysis, in the non-parous group. 
The sex ratio for the lambs recovered from the two groups of ewes, male to female, was $1 \cdot 2: 1$ and $1: 1$ respectively.

\section{LAMBING DATA FROM FULL-TERM GROUP}

The following classification was used to grade the foetuses obtained from this group:

$\mathrm{F}_{1}$, Alive at birth.

$F_{2}$, Not alive but showing full body development.

$\mathrm{F}_{3}$, Mummified.

C, No lamb.

Table 6 presents the information obtained from those ewes that conceived to one service and were allowed to lamb.

TABLE 6

LAMB PRODUCTION FROM THOSE EWES ALLOWED

TO LAMB

\begin{tabular}{l|c|c}
\hline & $\begin{array}{c}\text { Parous } \\
\text { ewes }\end{array}$ & $\begin{array}{c}\text { Non- } \\
\text { parous } \\
\text { ewes }\end{array}$ \\
\hline Total ewes conceived to one service & 65 & 52 \\
No. of ewes aborted & - & 1 \\
No. of ewes that lambed & 63 & 48 \\
No. of viable lambs & 77 & 41 \\
$\mathbf{F}_{1}$ & 7 & 15 \\
$\mathbf{F}_{2}$ & - & 1 \\
$\mathbf{F}_{3}$ & 2 & 3 \\
No. of no-lamb ewes (C) & & \\
\hline
\end{tabular}

From the sixty-five parous ewes and the fifty-two non-parous ewes that supposedly conceived to one mating (i.e. did not return to service), sixty-three and forty-eight ewes in each respective group subsequently lambed. The nonparous ewe that aborted did so at 138 days after mating. A total of eighty-four lambs $(129 \%)$, of which seventy-seven $(91.7 \%)$ were alive and seven $(8.3 \%)$ were dead, were obtained from the parous ewes. Fifty-seven lambs $(110 \%)$, of which forty-one $(71.9 \%)$ were alive, and sixteen $(28.1 \%)$ were dead, were obtained from the non-parous ewes. The percentage of total lambs born was calculated on the total lambs derived from the total ewes assumed to have conceived to one service. Of the sixty-three parous ewes that lambed, twentyone $(33.3 \%)$ produced twins but only seven $(14.6 \%)$ of the forty-eight nonparous ewes gave birth to twins. A total of five ewes failed to produce lambs. Post-mortem on these five ewes revealed that three were normal, one had an occluded Fallopian tube and the other had small inactive ovaries with both Fallopian tubes absent. The two ewes showing abnormalities were both nonparous.

The average gestation length was 147 days ( 141 to 153 days), and 147 days (143 to 152 days) and the sex ratio, male to female, was $1: 1.3$ and $1: 1.2$ for the two respective groups of ewes. 
SUMMARY OF ESTIMATES OF PRE- AND PERINATAL LOSS

IN THOSE EWES THAT CONCEIVED TO ONE SERVICE

Table 7 summarizes the estimated loss that occurred from coitus to lambing. This incorporates the data available from the 2-day slaughter group and from those ewes in subsequent groups that conceived to one mating and did not return to service. The loss was estimated on corpora lutea counts.

Table 7 presents the summation of the data detailed in the preceding tables. The preliminary 1963 investigation was valuable as a comparison to the results obtained in 1964 .

The data shown in Table 7 were calculated as follows. The true ovulation rate for the two flocks was that obtained from the 2-day slaughter groups.

TABLE 7

ESTIMATED PROGRESSIVE PRE- AND PERINATAL SURVIVAL/100 EWES THAT CONCEIVED TO ONE SERVICE

\begin{tabular}{l|cc|cc}
\hline & \multicolumn{2}{|c|}{$\begin{array}{c}\text { Parous } \\
\text { ewes }\end{array}$} & \multicolumn{2}{c}{$\begin{array}{c}\text { Non-parous } \\
\text { ewes }\end{array}$} \\
\cline { 2 - 5 } & 1963 & 1964 & 1963 & 1964 \\
\hline $\begin{array}{l}\text { Ovulation rate (\%) (2-day group) } \\
\text { Ova fertilized (\%) }\end{array}$ & 133 & 139 & 120 & 143 \\
\hline $\begin{array}{l}\text { Ovulation rate (\%) (18, 30 and } \\
140 \text { days) }\end{array}$ & 147 & 159 & 146 & 163 \\
$\begin{array}{l}\text { Less case C at 18 days } \\
\text { Less case B and degenerating A } \\
\text { embryos at 18 days }\end{array}$ & 138 & 151 & 134 & 158 \\
$\begin{array}{l}\text { Less loss between the 18 to 30 day } \\
\text { (case B-30 days) }\end{array}$ & 107 & 127 & 114 & 145 \\
$\begin{array}{c}\text { Less loss due to abortion or mum- } \\
\text { mification or death at 140 days }\end{array}$ & & 122 & 110 & 136 \\
\hline $\begin{array}{l}\text { Lambing } \\
\text { Less dead lambs at lambing } \\
\text { Actual lambing \% obtained }\end{array}$ & & $112 *$ & & 129 \\
\hline
\end{tabular}

* Estimated lamb production/100 ewes.

Table 2 showed that 97.5 and $91 \cdot 1 \%$, and 93.3 and $83.3 \%$ of the ova recovered from the parous and non-parous ewes in the 1963 and 1964 investigations were fertilized. These respective percentages of the 2-day ovulation rates provided an estimate of the potential lamb production following the loss through nonfertilization expressed as percentage of ova fertilized.

The calculation of degree of embryonic loss (excluding non-fertilization) was made from the mean number of corpora lutea counted/100 ewes recorded from the 18-, 30- and 140-day slaughter groups. The 18-day slaughter group (Table 3) provided a measure of three phases of loss. By deducting the percentage of the ova fertilized that were classed as case $C(6.1$ and $8.3 \%$, and 4.9 and $3.2 \%$ for the 1963 and 1964 parous and non-parous ewes respectively) the percentage of embryos alive at this stage was estimated. Similarly, by deducting the percentage of the ova fertilized that were case $B$ and degenerating $A_{3}$ 
embryos $(18.4$ and $22.2 \%$, and 20.4 and $10.8 \%$ for the 1963 and 1964 parous and non-parous ewes respectively) the potential percentage of embryos alive at 18 days was deduced.

Loss of embryos between the 18th and 30th day was calculated on the percentage of degenerate membranes (case B) recovered from the 30-day slaughter group. Table 4 showed this to be $11.1 \%$ and $2.1 \%$ for the parous ewes and $3.2 \%$ and $6.1 \%$ for the non-parous ewes for the two respective observations. The potential lamb production at this stage was thus calculated by deducting these percentages from those embryos alive at 18 days.

From the 140-day slaughter group, Table 5 showed that $1.3 \%$ of the lambs from the parous ewes and $5.3 \%$ of the lambs from the non-parous ewes that were alive at 30 days either aborted, were mummified or showed full 140-day body development but were dead on recovery. The potential lamb production/ 100 ewes, immediately prior to birth ( 140 days) thus became $122 \%$ and $129 \%$.

Table 6 showed that $8.3 \%$ and $26.7 \%$ of the lambs born to the two groups of ewes were born dead. The total prenatal loss in these observations (excluding non-fertilization) became $23.3 \%$ and $20.9 \%$ for the parous and non-parous ewes respectively. Thus the total pre- and perinatal loss was $29.6 \%$ and $41.7 \%$ for the two respective classes of ewes.

\section{DISGUSSION}

The ovulation rates for the respective 2-day groups appear low, although little published information is available for $2 \frac{1}{2}$-year-old New Zealand Romney Marsh ewes for comparison. The pre-mating body weight of the parous ewes was similar to that for the same age group in flocks in the southern North Island (114 lb in 1963 and $111 \mathrm{lb}$ in 1964).

The fertilization rates of recovered ova of $97.5 \%$ and $91.1 \%$ for the parous ewes are comparable to those obtained under natural mating conditions by other workers in this country. In association with fertilization rate it is desirable to consider the data available from these observations on return rates to one service. In the 1963 investigation $3.1 \%$ and $17.9 \%$ of the parous and nonparous ewes were not pregnant at 2 days (i.e. non-fertilized ova only were recovered) although $15.8 \%$ and $27.9 \%$ of ewes returned to one service. Similarly, the 1964 data showed $14.3 \%$ and $17.4 \%$ of ewes were not pregnant at 2 days whereas $20.4 \%$ of the parous and $26.3 \%$ of the non-parous ewes returned to service. This strongly suggests that embryonic mortality could play a significant role in return rate to service in the ewe.

The average inter-oestrous period, in those ewes that did return to service, was 17 days, with a range of 15 to 18 days. In not one instance, throughout the entire 1963 and 1964 observations, did any one ewe experience a protracted inter-oestrous period which is a common phenomenon following early embryonic loss in the repeat-breeder cow.

In these observations one of the major factors that could influence fertilization rates was the incidence of genital tract abnormalities. $6 \%$ of the parous and $15 \%$ of the non-parous ewes showed some abnormality.

It is apparent from Table 7 that the period of maximum embryonic mortality 
was in the first 30 days of pregnancy. Similar data were obtained during the 1963 investigation. The data obtained from the 18-, 30- and 140-day slaughter groups also revealed a higher degree of embryonic mortality in twin rather than single ovulations. Of those ewes showing a twin ovulation $47.1 \%$ and $54.9 \%$ for the 1963 and 1964 observations respectively, retained both as two live embryos, $47.1 \%$ and $43.2 \%$ showed evidence of one embryo only being alive and $5.8 \%$ and $1.9 \%$ gave evidence of both being lost. These data, although of some importance, apply only to ewes that did not return to service. As it is impossible confidently to deduce what degree of mortality occurred in single and twin fertilized ova, in the ewes that returned to service, any overall estimate of the comparative mortality that did occur is difficult.

Prenatal loss after 30 days appeared negligible although the 140-day group could only provide data on abortions which occurred in two ewes 121 and 129 days after mating, but comparison of the non-viable products at 30 days (Table 4) closely parallels that of the non-viable material (case $\mathrm{C}$ only) at 140 days (Table 5 ).

The lambing performance closely resembles that obtained from field survey studies in both pedigree and commercial flocks with an $8.3 \%$ perinatal lamb loss, $3.1 \%$ no-lamb ewes (these had supposedly conceived but had failed to produce a lamb), a $28.6 \%$ assistance rate at birth and a $13.1 \%$ malpresentation rate in those lambs that were assisted. Thus with these similarities existing it could be assumed that the performance of the parous ewes, at least, closely parallels that of ewes of a similar age group in flocks.

\section{ACKNOWLEDGMENTS}

The authors are indebted to both Dr D. G. Edgar, Ruakura Animal Research Station, and Dr M. F. MacDonald, Massey University of the Manawatu, for technical advice, particularly in the preparatory stages of both investigations; to Dr D. P. Boshier, Faculty of Veterinary Science, Massey University of the Manawatu, for the histology on the 18-day-old embryos during the 1964 observation; and to Miss B. D. Matthews for technical assistance throughout the study.

The generosity of those Romney Marsh breeders who made their sheep available for these investigations is gratefully acknowledged.

\section{REFERENCES}

Brambell, F. W. R. (1948) Prenatal mortality in mammals. Biol. Rev. 23, 370.

CAsida, L. E. (1953) Prenatal death as a factor in the fertility of farm animals. Iowa St. Coll. F. Sci. $28,119$.

DuTr, R. H. (1954) Fertility rate and embryonic death loss in ewes early in the breeding season. 7. Anim. Sci. 11, 464 .

Green, W. W. \& Winters, L. M. (1945) Prenatal development of the sheep. Tech. Bull. Minn. agric. Exp. Stn, No. 169.

Hammond, J. (1921) Further observations on the factors controlling fertility and foetal atrophy. 7. agric. Sci. 11, 337.

Hanly, S. (1961) Prenatal mortality in farm animals. F. Reprod. Fert. 2, 182.

Henning, W. L. (1939) Prenatal and postnatal sex ratio in sheep. F. agric. Res. 58, 565. 
Hulet, G. V., Voigtlander, H. D., Pope, A. L. \& Casida, L. E. (1956) The nature of early season infertility in sheep. 7. Anim. Sci. 15, 607.

Laing, J. A. (1952) Early embryonic mortality. Proc. IInd int. Congr. Physiol. Path. Anim. Reprod., Copenhagen, 2, 17.

Radford, H. M., Watson, R. H. \& Wood, G. F. (1960) A crayon and associated harness for the detection of mating under field conditions. Aust. vet. F. 36, 57.

Robinson, T. J. (1957) Pregnancy. Progress in the Physiology of Farm Animals, p. 793. Ed. J. Hammond. Butterworths, London.

Winters, L. M. \& Feurfel, G. (1936) Studies on the physiology of reproduction in the sheep. IV. Fetal development. Tech. Bull. Minn. agric. Exp. Stn, No. 118. 